\title{
Laughing across borders: Intertextuality of internet memes $^{1}$
}

\section{Liisi Laineste}

Estonian Literary Museum / Centre of Excellence for Estonian Studies liisi@folklore.ee

\section{Piret Voolaid}

Estonian Literary Museum / Centre of Excellence for Estonian Studies piret@folklore.ee

\begin{abstract}
Internet humour flourishes on social network sites, special humour-dedicated sites and on web pages focusing on edutainment or infotainment. Its increasing pervasiveness has to do with the positive functions that humour is nowadays believed to carry - its bonding, affiliative and generally beneficial qualities. Internet humour, like other forms of cultural communication in this medium, passes along from person to person, and may scale (quickly or gradually, depending on the comic potential and other, sometimes rather elusive characteristics) into a shared social phenomenon, giving an insight into the preferences and ideas of the people who actively create and use it. The present research is primarily carried by the question of how the carriers of Internet humour, that is, memes and virals, travel across borders, to a smaller or greater degree being modified and adapted to a particular language and culture in the process. The intertextuality emerging as a result of adapting humorous texts is a perfect example of the inner workings of contemporary globalising cultural communication. Having analysed a corpus of 100 top-rated memes and virals from humour-dedicated web sites popular among Estonian users, we discuss how humour creates intertextual references that rely partly on the cultural memory of that particular (i.e. Estonian-language) community, and partly on global (primarily English- and Russianlanguage) cultural influences, thus producing hybrid cultural texts. The more interpretations are accessible for the audience (cf. polysemy Shabtai-Boxman \& Shifman 2014), the more popular the text becomes, whereas the range of interpretations depends on the openness of the cultural item to further modification.
\end{abstract}

Keywords: Estonian jokelore, internet humour, intertextuality, memes, virals, visual humour. 


\section{Introduction}

This article deals with one of the central characteristics of the internet: the practice of sharing humour. Humour flourishes on social network sites, special humour-dedicated sites and on web pages focusing on edutainment or infotainment. Its ubiquity has been noted since the dawn of the internet, e.g. in the early study of Baym (1993), where she argues that humour is a frequent and highly valued element of online communication. Whether it is appreciated because of its way of bringing people together (Baym 1993, 1995), just as an entertaining online "duel of wits" (Danet et al. 1995, 1997) or for any other reason, the importance of technologically mediated humorous self-expression is a phenomenon that needs more recognition from scholars (see Blank 2013). It cannot be ignored because the internet is the place where people spend more and more of their time; it is a place where they, among other things, share folklore. Online and face-to-face communication is not two distinct activities but cooperate in folkloric dissemination of cultural texts.

In the internet, all sharing - not just sharing humour - emerges as central cultural logic. Shifman (2014) suggests that it encompasses both sharing as distribution (meaning just the activity of copying and pasting, forwarding, etc.), and sharing as communication (i.e. delivering a message by the act of sharing; e.g. creating/reinforcing group identity, showing one's expertise in internationally known cultural texts, mediating an important political point from grassroots level, etc.). Consequently, internet users are both distributors and active creators of cultural texts. These contagious, widely travelling pieces of cultural information are often referred to by the emic term as memes (see among others Knobel \& Lankshear 2007). A meme is a relatively complex, multi-layered, and intertextual combination of (moving) image and text that is disseminated by the active agency of internet users, becoming popular among them. The full set of meanings of a meme is recovered only by having a complete overview of the origin and history of its development (Lin et al. 2014), but it is open to various interpretations as well. Image macro is an alternative term for a static image and text memetic unit, designating re-usable images usually embedded in a frequently repeated background and accompanied with a text (e.g. "advice animals", see Vickery 2014). In this paper, we will also use terms like cultural item or cultural text to designate shared and popular (often humorous) folkloric objects on the internet.

Recent research stresses the importance of differentiating between memes and virals and seeing them as two ends of a dynamic spectrum. Virals are single cultural units that are spread and viewed by millions of people, whereas a meme is always a collection of texts (Shifman 2014: 56-58). The focus will be on the two ends of the dynamic scale, in order to point at the differences in their patterns of dissemination. It is clear, however, that human agency - the choice of forwarding/modifying/commenting on/liking etc. a meme or a viral is essential in the diffusion of these items of digital culture. Memes or virals do not replicate themselves like Dawkins suggested in the early days of meme research (Dawkins 1976); instead, their circulation beyond their immediate social networks of the disseminators is guided by the tactical decisions of the people who use them.

For a long time, the better-travelled humorous items of fixed content mostly dwelled on general popular topics such as sex or animals (Shifman 2006: 199). Just a fragment of them focused on politics, nations, or specific, locally known group stereotypes. Topics such as the former translate easily, as do jokes about general stupidity (for the history and spread of stupidity jokes, see Davies 1990 and later). Using general script oppositions (e.g. smart/dumb) guarantees openness to editing, recycling, and interpretation.

English, having become the lingua franca of the internet, often appears as the main language of humorous texts, which further supports globalisation. Due to the increasing access to internet that has skyrocketed in other cultural and linguistic spaces besides English 
as well, translations, remixes (Knobel \& Lankshear 2008), and local adaptions of global internet humour are more frequent. Thus, from the late 2000s onwards, online meme culture has witnessed a continuous increase of more localised internet memes (Börzsei 2013). The blending of the global and local planes brings faraway issues closer (e.g. the Occupy Wall Street movement and its local expressions; see Blank 2012: 9-12; Sparke 2013) and, similarly, allows the local topics to gain a wider international audience and recognition (e.g. the Tahrir square events in 2011, see Helmy \& Frerichs 2013). Memes and virals, all in all, offer a current, up-to-date and poignant public commentary of important events, employing a universal language relying on popular culture (Milner 2013; Häkkinen \& Leppänen 2014).

While sharing cultural texts, internet users make use of and create social memory through becoming engaged in an active dialogue with previous cultural texts and with potential audiences. Intertextuality (both within and across cultures) should thus be highlighted as a central feature that lies at the crossroads of the medium, the people and the message. This is a term that has acquired an important position together with the rise and development of internet culture. In humour research, it has traditionally been used in the context of a humorous text referring to another, earlier text, as in parody (Ross 1998). The reference(s) may shape the meaning depending on the availability of the reference frames of the audience. It is probably not possible to bring to daylight all the possible sources of influence and inspiration of a particular item of humour (Coulson 2015), but locating specific (linguistically or otherwise specified) cultural texts within the wider global arena is informative both of the global tradition as well as of the choices and preferences of the carriers of that particular culture.

In this context, several concepts have been added to the methodological toolkit of digital culture researchers to give an insight into the adaption process. One of these is resemiotisation, whereby content is lifted from a text in the source domain and recast in a modified form during the production of a subsequent derivative text in the target domain. This concept illustrates the way new memes are formed. Bauman \& Briggs' (1990) concept of entextualisation is another useful term to describe rendering coherent stretches of discourse which are discontinuous with one's discursive surroundings, through meaningmaking, i.e. adjusting cultural texts so that they become meaningful and relevant to the target culture (see Leppänen et al. 2014). The notion helps to describe how different groups and individuals interpret and de- and retextualise the same cultural units (cf. Miltner 2014). These can be seen as complementing terms to illustrate various aspects of the process of intertextualisation.

Intertextuality is not new for humour, and has been argued to be, for example, an essential element of parody (Berger 1995: 73; Hutcheon 2000). Intertextuality may occur in conversation when a joke or a part of it is used to strengthen, embellish, or underline the message (Oring 2003; Laineste 2015). It may also occur between humorous texts, where one joke refers to (many) previous others (Graham 2009: $83 \mathrm{ff}$.). When humour travels across borders and between nations and cultures, it acquires new interpretations - not just through translation but also through adjusting the text to the target culture, at the same time retaining a connection with the source. If the text becomes popular, this is an indication that the adaption was successful. This was the case with ethnic stupidity jokes, as Davies (1990: 15) states: "[E]thnic jokes about stupidity are easily transferable between different groups all over the world because people in different countries and cultures increasingly seem to have a common view of what constitutes stupidity" (the mechanisms that underlie this process are described in Davies 2011). However, sometimes a text that can be interpreted as critical commentary loses its meaning in a new context (see the example of elephant jokes below). 


\subsection{Soviet jokes in Eastern Europe}

A transmission of humorous texts from one language and culture to others was also successfully performed by the Soviet totalitarian jokes, where jokes moved from the Russianlanguage centre to various smaller Soviet satellite state peripheries. The last decades of the Soviet Union are often referred to as the "golden age" of joke-telling (and after 1980s jokes began circulating also in published form; see Graham 2009: 122). Soviet jokes were well known all around the Eastern bloc. Everyone from Tallinn to Tirana, from Prague to Minsk knew similar jokes about the totalitarian system, the continuous shortage of goods in the stores, and the leaders who were not on a par with their duty to the state. They all told jokes about the legendary, although rarely spotted ethnic character, the Chukchi (Draitser 1998), about the cruel pet peeves of Stalin (Krikmann 2004), etc. The new life that old Soviet jokes live in present times can be seen as some sort of an identity marker for Eastern European humour or a local flavour (for the case of Estonia, see Laineste 2009). While describing Russian present-day humour, Graham (2009) draws attention to the numerous Soviet motives alluded to in post-Soviet humour. Alternatively, a sudden re-actualisation of old jokes may happen when a political situation or a particular event so requires (e.g. in Belarusian contemporary jokelore; see Astapova 2015). Intertextuality with old Soviet motives may arise also from nostalgic motivation (Laineste 2012). The absurdness of Soviet times, however appalling we now consider it to have been and how little we want it to return, is again and again called back in jokes, humour serials, even museums and tourism. ${ }^{2}$ Sincere nostalgia is balanced off with a fair share of irony and humour, which makes such trips to the past appealing to many. Nostalgic recollection in itself can acquire an entertainment value (Graham \& Mesropova 2009).

Soviet jokelore was so influential that even today in Eastern Europe (if not wider) the same punchlines are used in various intertextual examples of internet humour. It is noteworthy how the textual jokes popular in Soviet times can now be found in online contexts in the format of visual memes. Examples also include usages contextualised to present-day politics, be it in the form of a citation or a full joke. Putin jokes (see Figure 1), for instance, often borrow from the earlier Vovochka jokes (see Adams 2005).

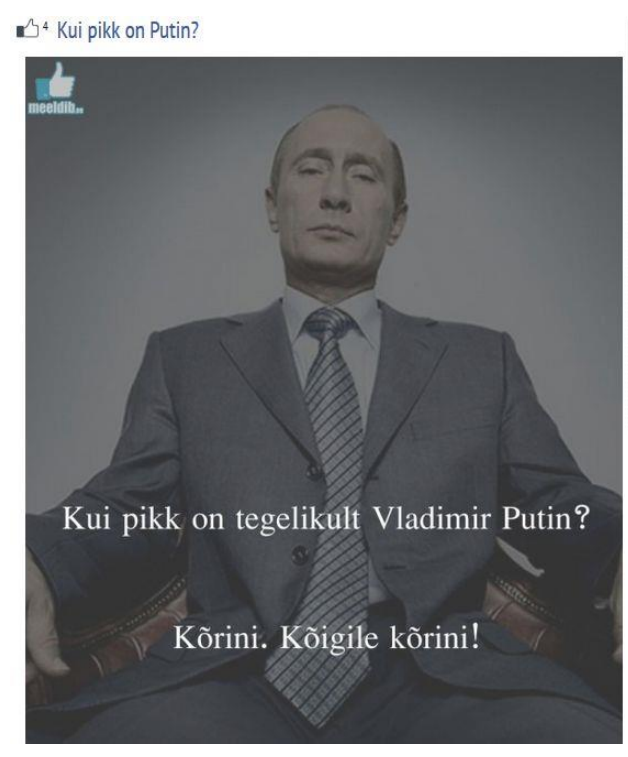

Figure 1. How tall is Vladimir Putin? - Up to the throat (= fed up). Up to the throat for everyone! (meeldib.ee) ${ }^{3}$ 
Another example of how an old Soviet joke has acquired a new life is the following conundrum joke:

- What are the three victories (kolm võitu) of the Estonian republic?

- Too little (or, alternatively, no victory to mention; vähevõitu), too expensive (already moving further from the initial reference to victory; kallivõitu), too bad (viletsavõitu) (võitu meaning victory, and the homonym võitu being similar to the English ending -ish or "kind of").

The original text from Soviet times addresses the three main victories of the Soviet Union (an example collected in $1985^{4}$ ). The replacement of the Soviet Union with the Estonian Republic is easy in jokes, given that the topic addresses the low quality of life standards or the stupidity of the political leaders. The comparison sometimes extends to the European Union (less so in jokes, but very often in colloquial political discussion, e.g. in online forums; see Laineste forthcoming). The next example (Figure 2) depicts two politicians active in the present day sitting next to a woman in traditional attire. The woman, citing an old Soviet joke about the totalitarian system, expresses thus her scepticism towards the situation in present-day Estonia, claiming indirectly that life in the republic of Estonia is not much different from that in Soviet Estonia. ${ }^{5}$

\section{Millised on Eesti Vabariigi kolm suurt võitu?}

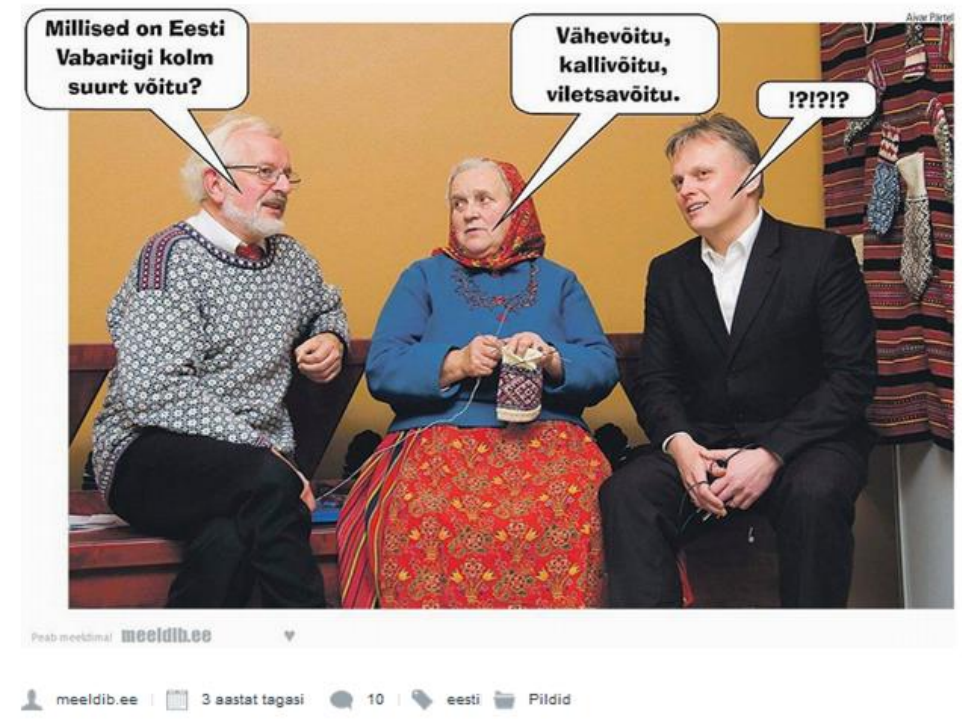

Figure 2. - What are the three victories of the Republic of Estonia? - Too little, too expensive, too bad (meeldib.ee)

From these examples a common element stands out: it is often jokes about politics and ethnic groups that travel by resemiotisation. They are adapted to the target culture so as to render them meaningful to the audience. In present days, this role can be filled by groups of memes. They are like a new language commenting on ongoing issues, salient problems, and scandals (see also Börzsei 2013).

\subsection{Well travelled blonde and elephant jokes}

A different pattern can be recognised in other jokes that travel well, but do not give rise to numerous local variations. In the late 1990s, a new favourite international character emerged in Estonian question-answer type jokes - the blonde. The so-called dumb blonde jokes came 
into circulation in Estonia in mid-1990s when after the regained independence the Estonian society suddenly opened up to the Western world and lifestyles. In the context of Estonia, it makes sense to draw a parallel between the blondes of the jokes and the Barbie doll image representing a beauty ideal of the Western society, because both the Barbie doll (which Mattel has been selling since 1959) and the blonde jokes using the dumbness script arrived in Estonia around that time. The first appearance of the cycle of dumb-blonde jokes in the USA was not much earlier: it swept across the country in 1991 (see Oring 2003: 59). In the Estonian material recorded during the 2007 school lore collection campaign, roughly a third of all conundrums collected were blond jokes (Voolaid 2011: 209). Jokes ridiculing the stupidity of blondes can be, on the one hand, a protest against the beauty ideals unattainable by a common person or motivated by the wish to compensate for the disappearance of gender roles in a society striving for equality of men and women. According to the Wienkler-Piepho (1998), blond jokes eminently highlight the unsurpassable stupidity of women, while Oring (2003: 70) argues that instead of being a broad-scale attack on women, these jokes serve as an indication of a misfit between entrenched stereotypes and the new expectations for women in contemporary society. Illustrated memes use the blonde as the target, but rarely an image of blonde women features on the background.
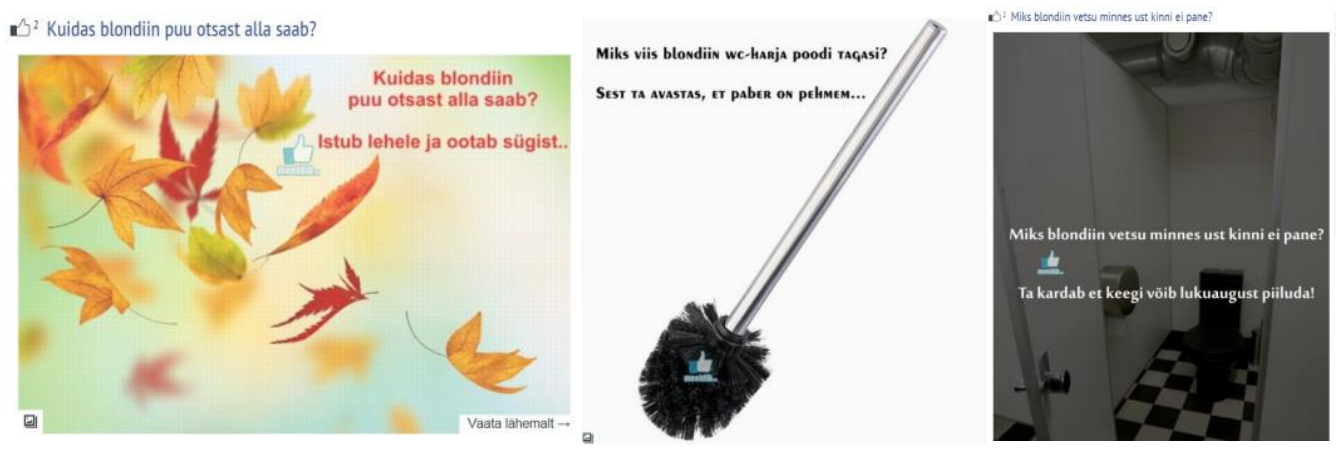

Figure 3. (3/1) How does the blonde get down from a tree? She sits on a leaf and waits until the autumn comes ${ }^{6}$. (3/2) Why does the blonde take the toilet brush back to the store?

Because she discovered that paper is much softer. (3/3) Why doesn't the blonde shut the bathroom door when going to the toilet? She's afraid that someone might peep in through the keyhole (meeldib.ee)

The same applies to elephant jokes: the pattern of these jokes is rather rigid, so their dissemination resembles more that of a viral than a meme, although they are translated into different languages. That said, we have to remember that there are always cultural differences in the ways jokes adapt and/or are interpreted in target cultures. One and the same joke can carry different meanings for different audiences. For example, in the psychoanalytically inclined article by Dundes \& Abrahams (1969), the elephant jokes are seen as a part of the civil rights movement in the USA. The size, colour, and strength of the animal are seen as metaphors for Black masculinity threatening the white middle-class way of life. Such racial implications certainly cannot be observed in Estonian elephant jokes that circulate purely as playful absurdity, nor in their scholarly interpretations (e.g. Voolaid 2010b: 37), and they remain the most popular riddle jokes (also known as joking questions) among school children today. 


\subsection{Internet humour in Estonia}

As this introductory overview suggests, jokes do not acknowledge country or culture borders and have always travelled from one to another, their dissemination patterns varying in the same way as was described by Shifman (2014) when describing memes and virals as two ends of a scale rather than a binary dichotomy. In the course of dissemination, they acquire different meanings, but also retain and introduce elements that come from the source culture. It has been posited that in online contexts, visuality might promote the spread of memes (ibid: 161), making them more available for internet users as linguistic barriers are minimised in an image. The reason behind this is that this simple and flexible combination of stimuli can convey messages faster and probably even more effectively than pure text (Buchel 2012) and in comparison with other formats (i.e. audio or video), it requires much less proficiency with specialised software. Some popular macros are deliberately amateur, like Rage comics, as if in opposition to "real" photo processing, again partly to invite extensive collaboration from other users. Successful memes, as Knobel \& Lankshear (2005: 6) define them, include one or more of the following characteristics: (1) some element of humour (absurd, parodying, geeky, etc); (2) rich kind of intertextuality, such as wry cross-references to different popular culture events, icons, or phenomena, and/or (3) anomalous juxtapositions, usually of images. As is common to all folkloric processes, memes and virals are created by the community and not authored by a single user (although the increase of attributed authorship is noticeable; see Gorny 2005: 299). Even if we are talking about memes that refer back to a single traceable item circulated widely in the beginning of dissemination process (as Shifman 2014: 59 calls them, founder-based memes; e.g. the "Leave Britney alone" meme), the origin of such cultural texts is less important than the successive derivations and adaptations.

Like other forms of cultural communication in this medium, internet memes and virals are passed on from person to person. Having analysed a corpus of 100 most popular (toprated and most frequently forwarded) videos and images on dedicated humour or social media sites popular among Estonian users, we will focus on the following descriptive research questions:

RQ 1. What are the main properties of the memes and virals that are popular among Estonian users? How are they modified and adapted to a particular language and culture in the process of dissemination?

RQ 2. What are the topics that inspire virals and memes?

To answer the questions, we will focus on two major types of internet-based cultural texts: virals that are distributed via sharing only and without any modifications, and secondly memes that are modified and adapted before sharing; adding visual and textual references to local culture is common in this category (like in creative dubbing of foreign videos on YouTube into Estonian in order to create humorous effects). The locally originating memes often use a "global model" of meme circulation to start off a local meme. Local motives are successfully combined with global forms and elements (e.g. pasting the verbal part of the humorous unit onto universal visual meme backgrounds). The opposite - using Estonian memetic images with a recognisable English/Russian textual part - is very rare. On the whole, it is the images that travel well in their original form, whereas the text (translated, original, or completely altered) needs more adjustment. This suggests that the visual side usually makes the base of the meme (an exception is the format of old Soviet jokes with a random, non-memetic visual background - like the blonde joke examples above, where the textual element dominates), whereas the text adds news layers of meaning. 


\section{Methodology}

The dataset includes material from the past six years (2011-2016). We compiled a list of items of visual humour based on two main sources: (1) Estonian major websites dedicated to humour $^{7}$ and (2) browsing for Estonian users on (a) global meme sites ${ }^{8}$ (b) social media sites such as Facebook and (c) video sharing sites such as YouTube. This work is part of a larger work on contemporary folklore on the internet carried out in CEES. ${ }^{9}$ The sources were selected according to their popularity rating (a combined number of likes, shares/forwards, and comments as the indicator). Estonian users on international sites were chosen by cumulative method, starting from one user and following his/her social network in the environment. Additional information was collected from discussion threads on the two most popular Estonian discussion forums Planet and Perekool ('Family school') ${ }^{10}$, naming the best humour that people had recently seen. This was done to cross-check if our observations were accurate to thus further validate the findings.

We then selected images/videos with the highest total number of likes, shares and comments using a python script that arranged the data according to the combined popularity rate, restricting the final sample to 100 humorous units (including duplicates from different sites). Although the motivation behind liking, sharing, and commenting varies, we decided to use them as equals in the combined popularity rate in this study and return to details in the next stages of this research. We focus on the most popular images/image groups to find out how particular topics spin off a huge amount of derivates (memes) and others disseminate mainly as one unit only (virals). To describe these two ways of dissemination, the final sample was categorised into two categories - virals and memes - by the authors. The categories were broken down into thematic sections (daily politics, animals, ethnic groups etc.). Qualitative data analysis tool QDA Miner was used that allows for tagging texts/images and later gaining an insight over their content and frequency. In the analysis we will only be focusing on the most popular examples from the biggest entertainment sites, ${ }^{11}$ because they are more influential in the creation and distribution of internet memes and virals.

\section{Results and discussion}

Examples from the categories and their analysis are presented below. The focus is on the second category -the locally adapted humorous memes- because of their highest level of intertextuality compared to virals and thus their highest potential of insight into the cultural process of globalisation/localisation of humour.

\subsection{Virals: Shared humorous videos and images without modifications}

A number of humorous videos and images are shared as they are. Such texts are significant from the point of view of folkloristics: the fact that some were forwarded and some others were not is telling about the preferences of the sender and his/her potential audience. Also Knobel \& Lankshear (2005: 13) in their typology differentiated between two types of internet memes based on replicability: the high fidelity static memes and the remixed ones which are "replicated via evolution, adaptation or transformation of the original meme vehicle".

The most obvious environments for this kind of memes are either global meme sites (where we followed the posts of users who have identified themselves as Estonians) or Facebook pages that mediate $9 \mathrm{gag}^{12}$ or other global site's content. However, also Estoniabased sites like meeldib.ee post content that is in English and in unmodified form. 
Animals, sex, and other "easy topics" often come without any additions and are thus the best examples of such visual-textual virals. LOLcats or advice animals are forwarded in English in the same format as they proliferate international online meme sites. Recurring topics are gender-related issues, references to sex, and expressing emotions about weekly work routine (Mondays and Fridays; often in combination with pictures about animals, e.g. cats; see Figure 4):
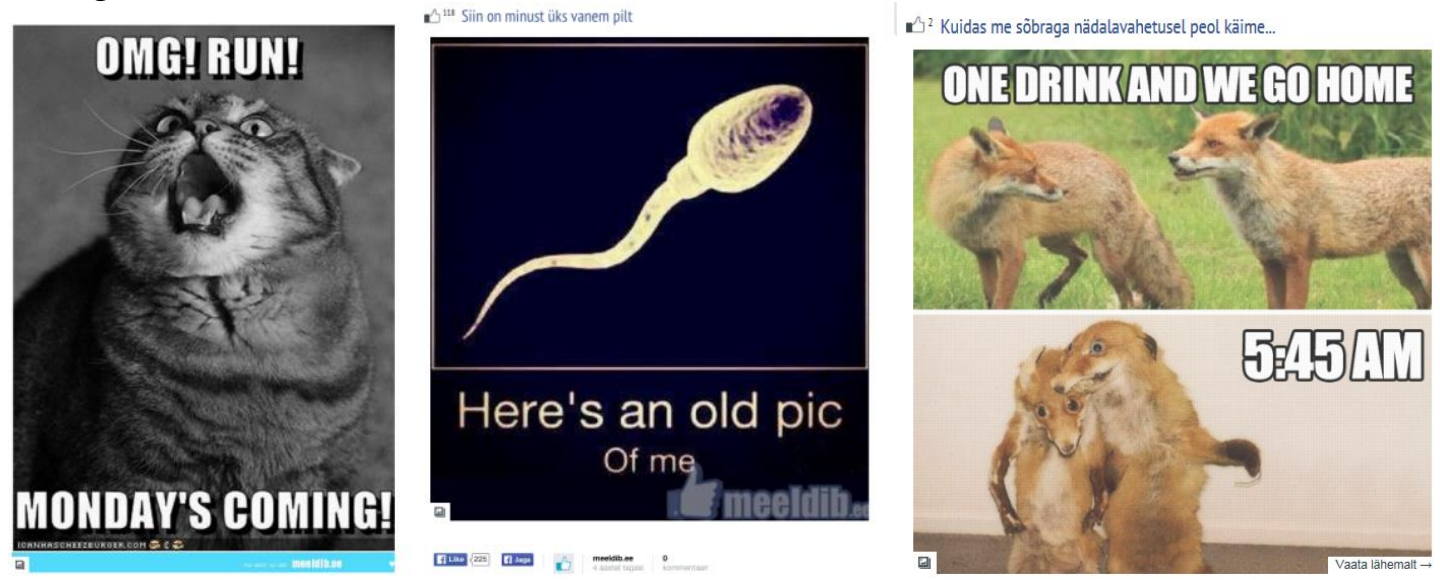

Figure 4. "Easy topics" forwarded without modification (meeldib.ee)

Another usual example is a commentary on internet user's online behaviour (Figure 5):

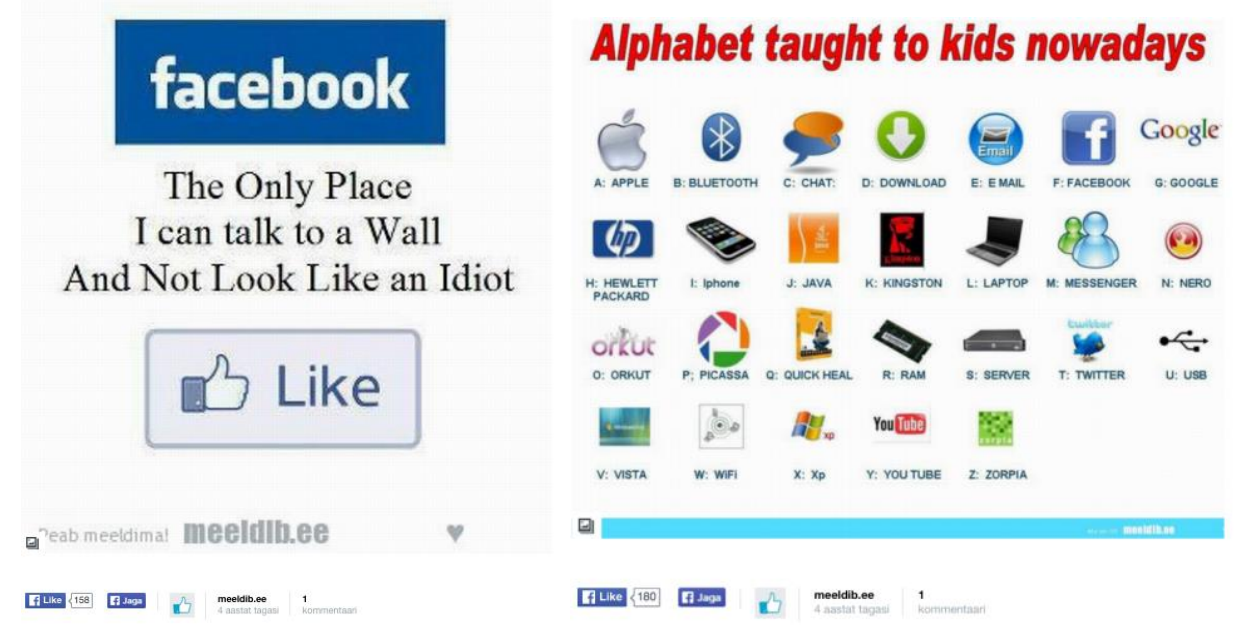

Figure 5. Online behaviour is a globally accessible topic. (meeldib.ee)

Among the more popular virals there are a few that ponder on political issues, although in this case, the lack of modifications is rather an exception than a rule. However, given that their topics are of international importance and their reverberations are in every type of (foreign) media including humour sites, it can happen that memes are just forwarded and no remixing occurs (Figure 6): 
igav.ee > Pildid
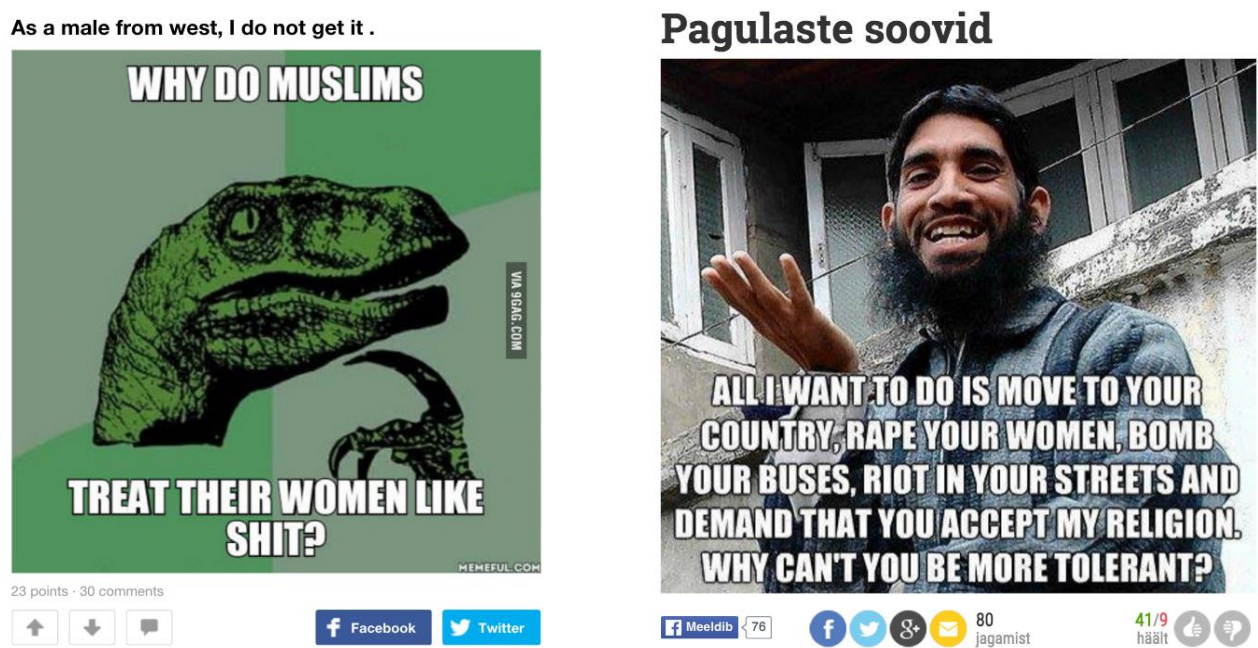

Figure 6. These images present the refugee crisis in 2015 as the topic of memes (memes.com; igav.ee)

The refugee crisis topic in folkloric circuit is the best example of intertextual remixes and localisation of global motives and patterns, which is why the second category (modified humorous memes) will mainly concentrate on the vernacular reactions to this topical issue. As the refugee crisis winds on, it is prone to inspire yet numerous memetic responses.

\subsection{Memes: Modified humorous videos and images}

A much bigger number of likes and comments is typical to pictures and videos that are derivatives of global memes, especially when compared to simple forwards/copies, although the distribution numbers (shares and forwards) in our sample were not as big as for the previous category. Which are the ones picked out for modification and why precisely these? There are a number of reasons (many of them are also pointed out in Shifman 2014; see also Knobel \& Lankshear 2005 on successful memes), one being that they must somehow connect to the idea or problem that the person recycling the meme wants to convey. Secondly, they should be readily available (the popular ones are more ubiquitous). Thirdly, they should not be too complicated; the most popular videos and photos are not the high quality ones. Rather the opposite is true: the low-fi shaky videos and blurry pictures prove to be accepted by the crowd as the most appealing. Remixing is made easy for the technologically savvy and the amateur alike, and incidentally some of the most frequently downloaded extensions and gadgets for web browsers are the ones that save YouTube videos for offline watching and editing.

One of the best-known and globally available memes is an extract from the movie Untergang ("Downfall", 2004). It depicts the pinnacle scene where Hitler is upset when he hears from his generals that the final counter-offensive against the Soviets never took place and Germany's defeat is imminent. Humour is produced by adding random subtitles or voiceover to the movie. There is a special YouTube channel for the so-called "Hitler rants parodies", where over thousand estimated derivative videos circulate with subtitles in English, Spanish, Chinese, Japanese, and many other languages, typically discussing matters from topical events to trivial news or gossip. In the Estonian versions, for example, the subtitles criticise the collapse of the ceiling in the cinema Artis in the centre of Tallinn, political events, the lives of prominent people, or the topical refugee debate where Hitler 
finds out that he in fact is a refugee, etc. Or, alternatively, the topic can be just as mundane as the fact that it is finally snowing outside.

A more recent memetic video on YouTube (and with a very similar emotional intensity in its content, although of a positive tone) is the one where the known Spanish comic Juan Joya Borja (celebrated for his contagious signature laughter; hence the nickname "El Risitas") talks to the host in the Spanish-language television program Ratones Coloraos. After telling a humorous anecdote about throwing kitchen pans into the sea while working at a beach restaurant as a young man, he bursts into laughter. This laughter is interpreted in various ways in the remixes inspired by it (e.g. El Risitas' reaction to Apple's new MacBook, and the videos' titles often start with "Shocking interview with..."). After the refugee crisis sparked off debates in more remote European countries such as Estonia, the video appeared with Estonian subtitles (Titled "An interview on the topic of refugees", screenshot on Figure 7).

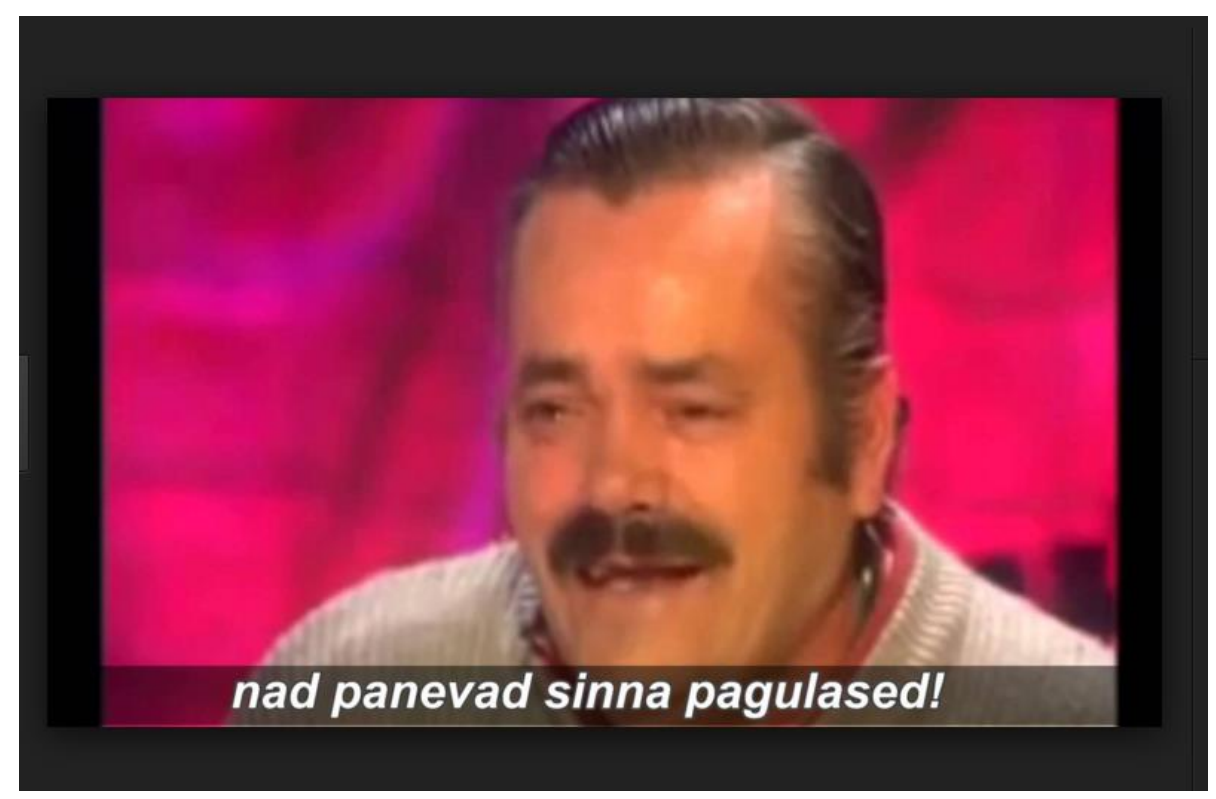

Figure 7. Screenshot from the video "An interview on the topic of refugees" ("They put refugees in there!") ${ }^{13}$

Concerning the local background of the refugee crisis, it is important to know that in line with the EU plan from July 2015 to distribute new asylum seekers across the European Union, Estonia agreed to eventually take in up to 500 refugees. At the same time, grim chapters in Estonian history, above all the Soviet occupation from 1944 to 1991, have kept national myths and images of the vulnerability of the Estonian culture and language alive. Adding to the fears is the fact that Estonians have had very scarce contacts with people of different skin colour. The history of granting asylum to refugees in Estonia is relatively short (officially since 1997) and displays numbers that are among the smallest figures in the EU (MINAS-5 report 2011). Estonia has not been an attractive destination for refugees because of the lack of jobs and the low living standards in comparison to other European countries and its northern neighbours. Approximately every fifth asylum application is granted. In the only refugee centre in Vao (a remote village in eastern Estonia), ca 70 refugees coming from 22 countries (Ukraine, Albania, Dagestan, and Georgia are the most frequent of them) live in relatively secluded conditions away from bigger towns like Tallinn or Tartu. In this context it comes as no surprise that humorous texts trying to figure out the effects of, and depicting the 
reactions to, the refugee crisis in 2015 abound on the internet. The usual modifications show a similar pattern: widely spread images are equipped with a new, localised textual part (Figures 8-11):
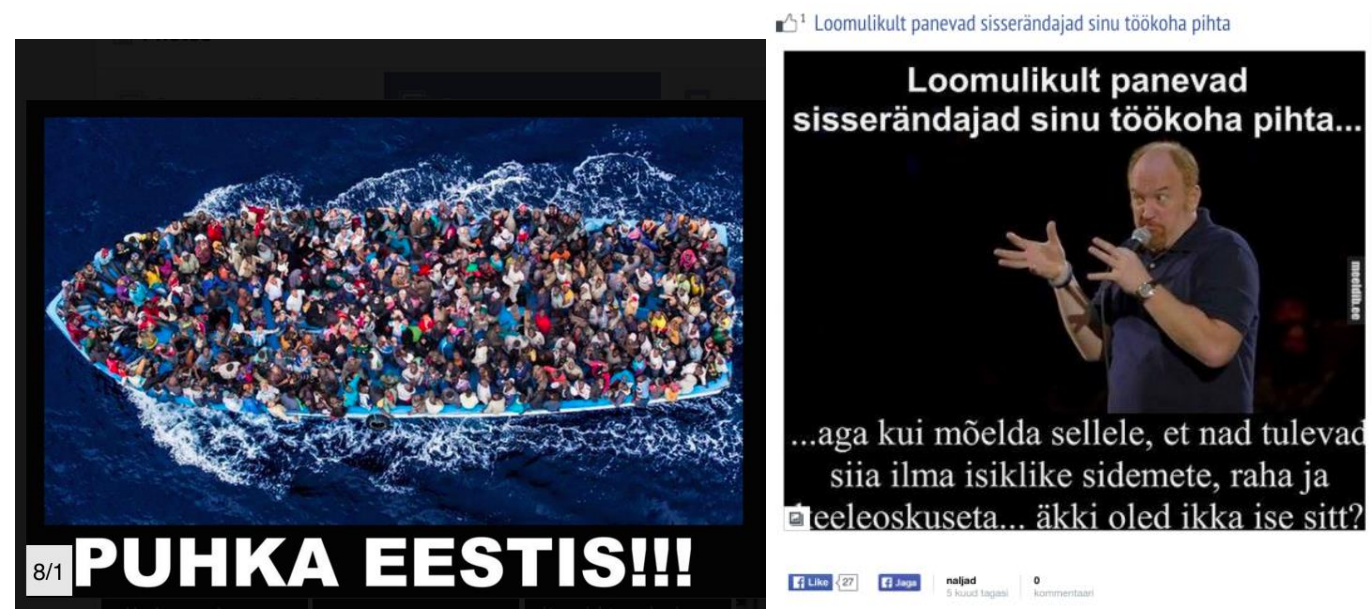

Figure 8. (8/1) Have a vacation in Estonia! (8/2) Of course the immigrants will snitch your job... but if you think that they come without personal connections, money and linguistic skills - maybe you are shitty yourself? (Facebook)

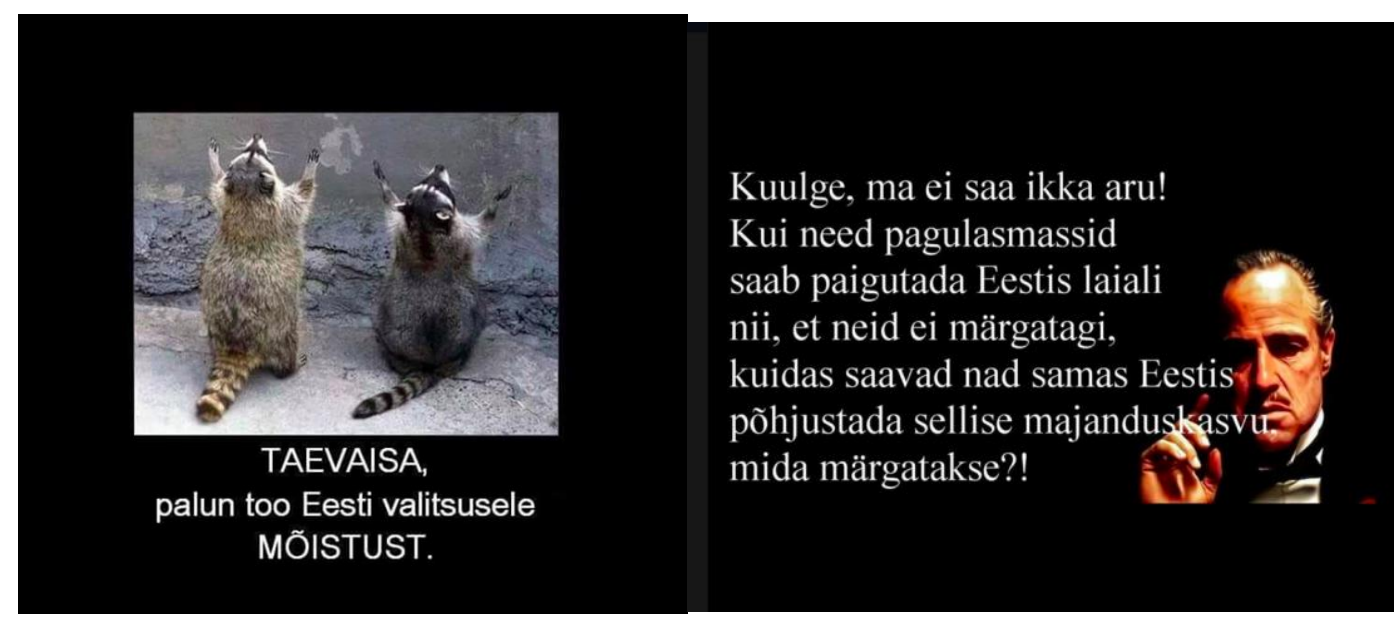

Figure 9. (9/1) Dear father in heaven, bring reason to the Estonian government. (9/2) Hey, I still cannot understand. If these masses of refugees can be distributed in Estonia so that nobody will notice them, how can they cause a noticeable economic growth?! (Facebook) 


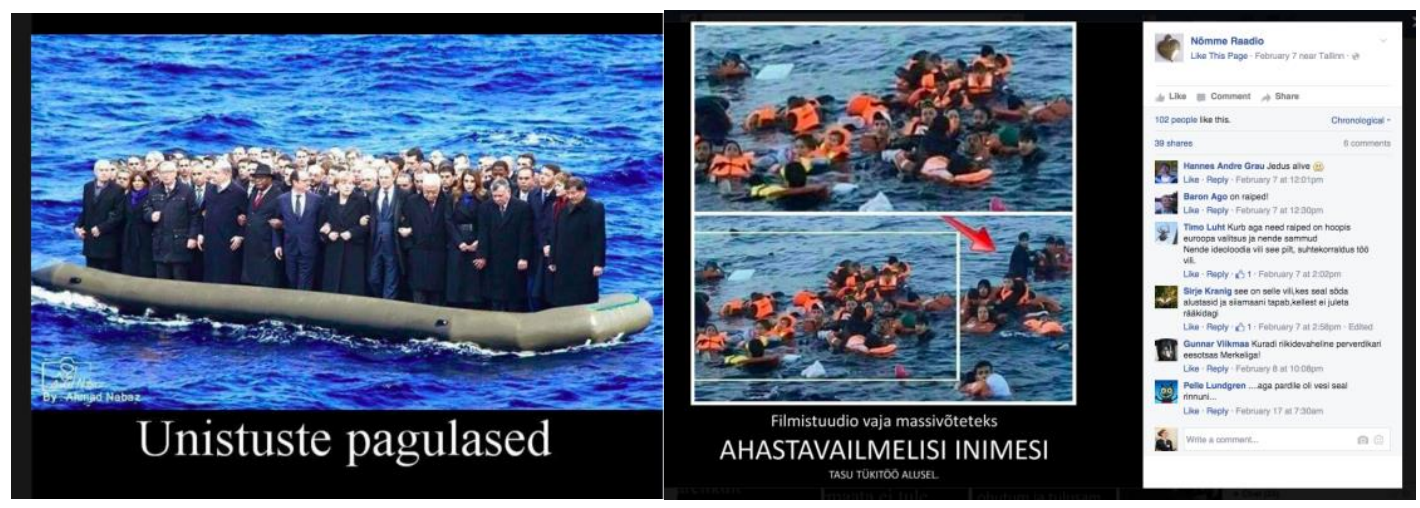

Figure 10. (10/1) The refugees of your dreams (10/2) Film studio is looking for people with desperate looks for movie shoots. Piece rates apply (Facebook)

A common motive is that of pigs and pork:
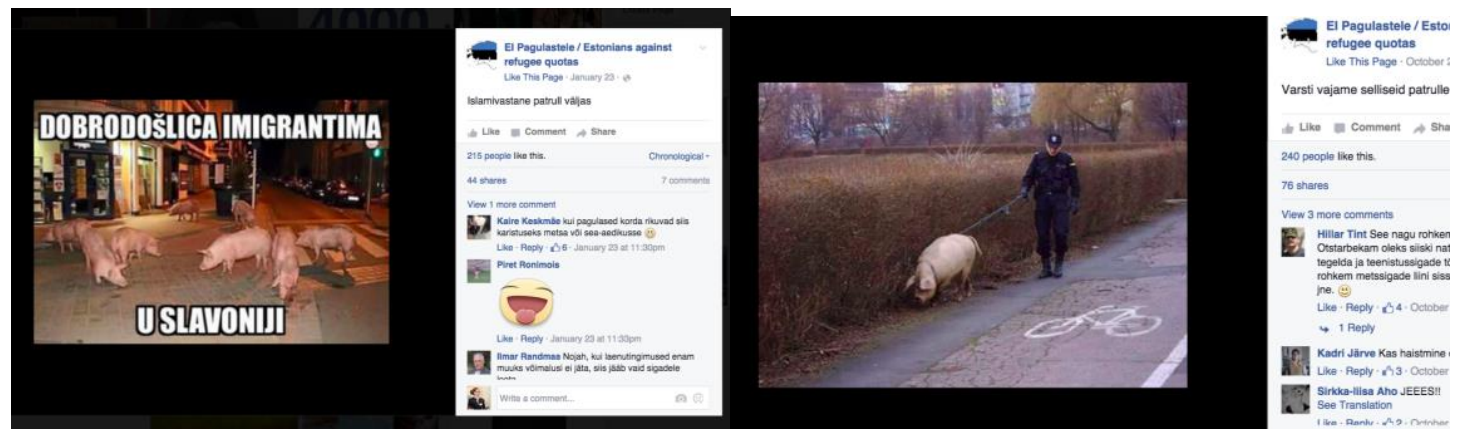

Figure 11. (11/1) Croatian image with Estonian comments, titled "Anti-Islamic patrol is on the guard". (11/2). New pig patrols to be introduced to keep the refugees under control.

(Facebook)

Estonian occupies a unique position because it takes memes not only from the Englishlanguage sphere, but also from the Russian area. There are several Russian posters that people use, but one of the most modified Soviet propaganda posters ${ }^{14}$ in Estonian internet is the poster fighting against alcohol "Нет!" ("No!") created by the famous Russian poster-artist Viktor Govorkov in $1954 .{ }^{15}$ In the Estonian context, the memetic replacement takes place primarily with local celebrities and scandalous politicians substituting for each other (Figure 12): 

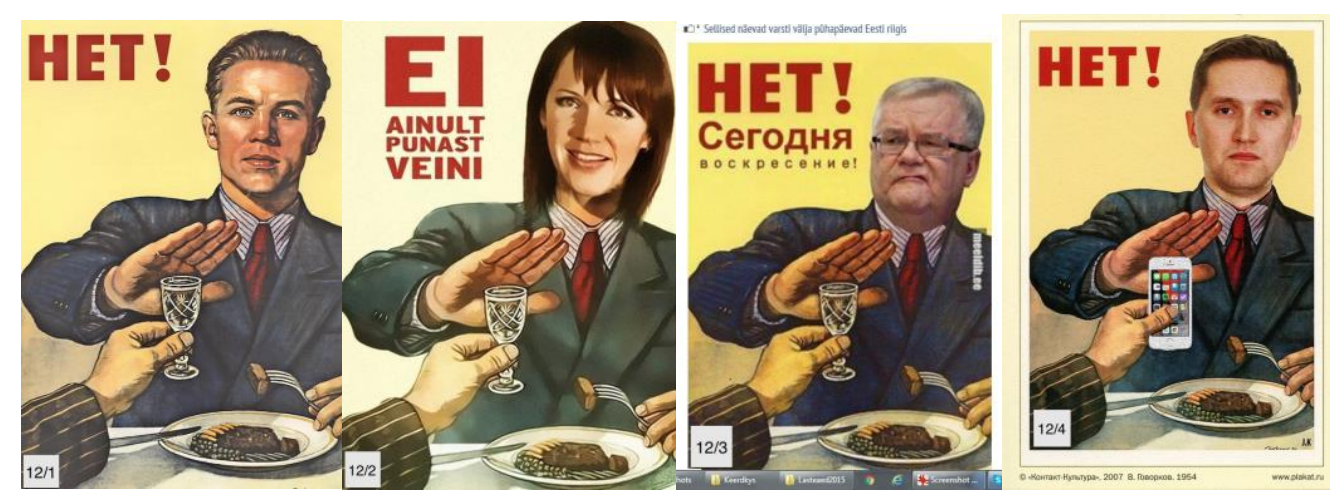

Figure 12. Development of a Soviet poster into memetic and productive cultural items. (12/1) the original poster; (12/2) local celebrity and religious singer Sõnajalg; (12/3) centre-left politician and mayor of Tallinn Edgar Savisaar; (12/4) politician Jaak Madison, the youngest member of the Parliament of Estonia, who was accused of appropriating a lost mobile phone

in his previous office and attempting to sell it in social media (meeldib.ee; Facebook)

Compared to others, intertextuality is most noticeable in these types of memes: the memes usually use widely known images/texts and add references to local events. Most often the mould is already available at this time, being popular at that very moment. Accommodation via references to local culture creates a feeling of recognition and commonality and renders the process of entextualisation smoother (e.g. when the viral video Harlem shake was transformed into the Estonian Freedom shake, or when the iconic Gangnam style video was dubbed to the well-known Nordic line dance called jenkka, etc.).

Similarly to what Kuipers describes in disaster joke cycles (Kuipers 2002: 454), development from language play to a more sophisticated play with meanings occurs in the 2015 refugee jokes. One of the early examples of refugee jokes was the following tweet including a play on words (Figure 13):

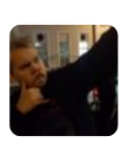

Karl Breemet @bremzzu · Sep 23

"Eesti on ainus riik, kes suudab migrante hoida Vaos, kui enam ei suuda, siis paneb nad Rakkesse ja kui see ka ei aita, siis saadab Tapale."

Figure 13. Estonia is the only country that can keep the refugees in Vao (the synonym of the place name vao meaning "under control"), and if they can't continue doing that, they put them in Rakke (another place name, synonymous with "make them toil hard") and if this doesn't help either, will send them to Tapa (place name synonymous with "send them to be executed")

A similar humorous visualisation from meeldib.ee (Figure 14): 


\section{${ }^{17}$ Briti teadlased on kindlaks teinud}

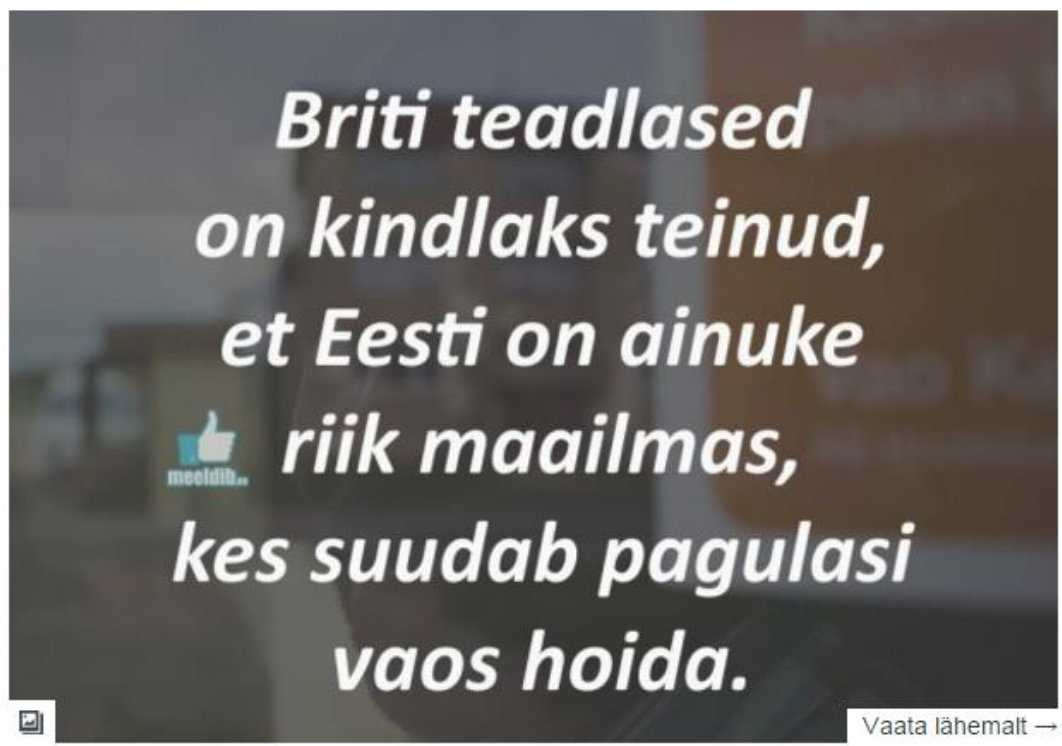

Figure 14. British scientists have proved that Estonia is the only country that can keep the refugees under control (or in Vao, the place) (meeldib.ee)

Directly connected to the aforementioned line of thought and also relying much on wordplay, the topic of cultural difference in foodways comes into the picture. Pork, the traditional (e.g. Christmas) food of Estonians, is transformed into an ironic symbol of alien refugees, the Other. It also refers back to the commonplace Estonian unwritten rule of eating up all the food on the plate, to food shortage memories from the Soviet times and WWII, to the idea that one should not pick at the food or play with it, and to the recent news of refugees rejecting humanitarian aid in the form of food packages with Red Cross (a Christian symbol) on them.

As soon as the first connection between refugees and their convictions towards eating to pork was renewed in the 2015 refugee crisis context, the idea found expression in completely local images circulating on humour sites (Figure 15):

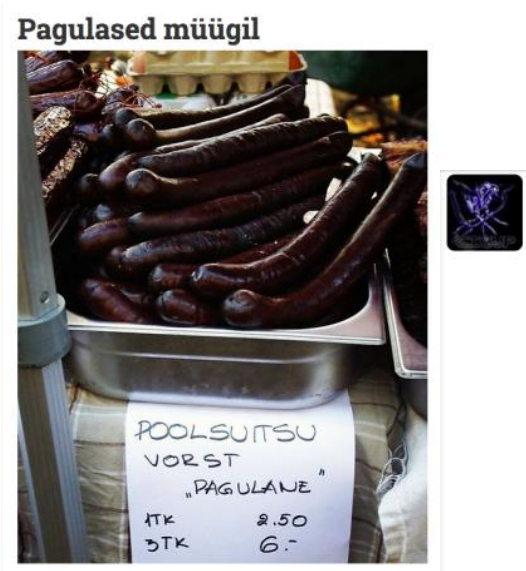

Laherand @sinu_hirm · Oct 7

Ole vait :'D :'D \#eestlased \#MUSThuumor

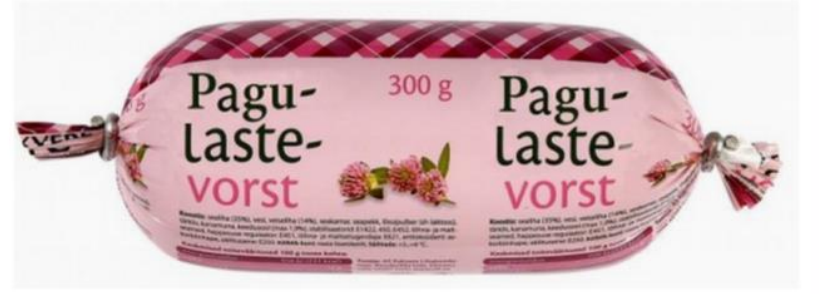

Figure 15. Half smoked sausage "Refugee" (15/1). "Refugee sausage" (15/2) - using the known sausage brand (Rakvere lastevorst or "children's sausage") and adding pagu(beginning of the word pagulane "refugee") to the widely known name; the name can thus mean sausage made for refugees or from refugees (meeldib.ee; twitter.com) 
The same pattern applies for alcoholic drinks. Drinking vodka (and holding one's liquor) has been a major subject in Estonian jokes. A label of the vodka Vao valge (with valge "white" being the regular part of various vodka brands in Estonia; e.g. Viru valge) circulated humour sites in autumn 2015 (Figure 16):

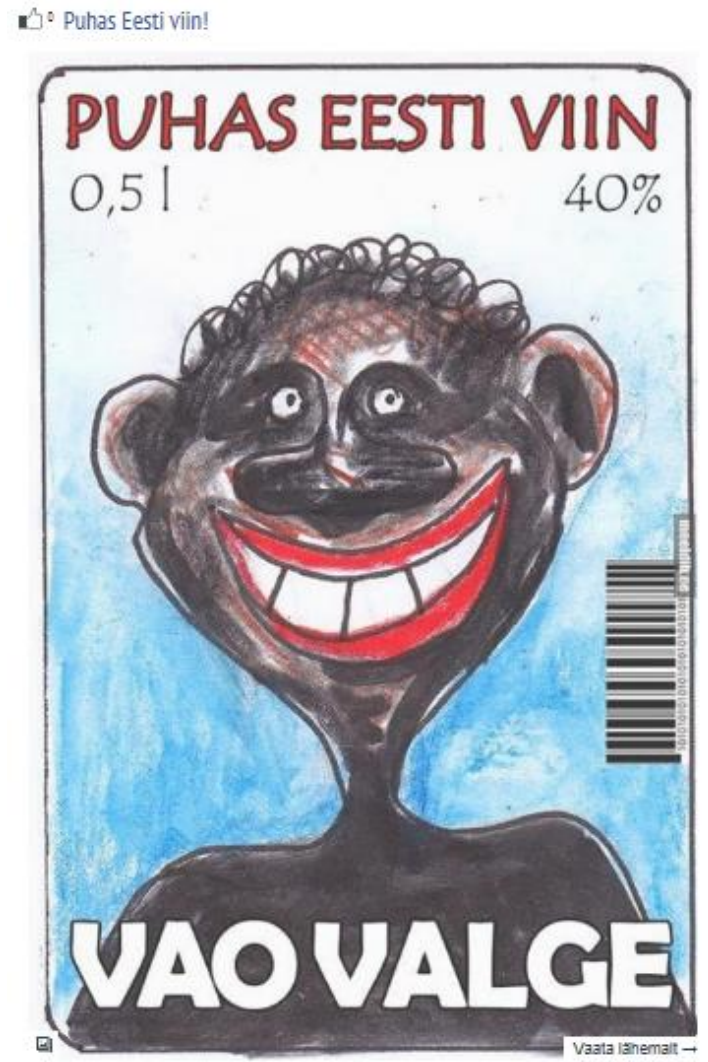

Figure 16. Pure Estonian vodka Vao White (meeldib.ee)

Local customs need to accommodate new influences. Such global currents in local customs are not just a play with ideas but may find a practical outlet. In the heyday of the viral video "Gangnam style", masked children going trick-or-treating on St. Martin's eve danced the iconic dance to their mobile phones in 2012, thus introducing new layers to ritual year customs. ${ }^{16}$ This is the case with many refugee-related humorous images as well. For instance, a popular one suggests how the Estonians need to reconsider the ways they celebrate St. John's eve. The memes shows a positive utopia of refugee integration into Estonian society: anti-refugee politicians and protesters take an active part in the festivities (Figure 17): 


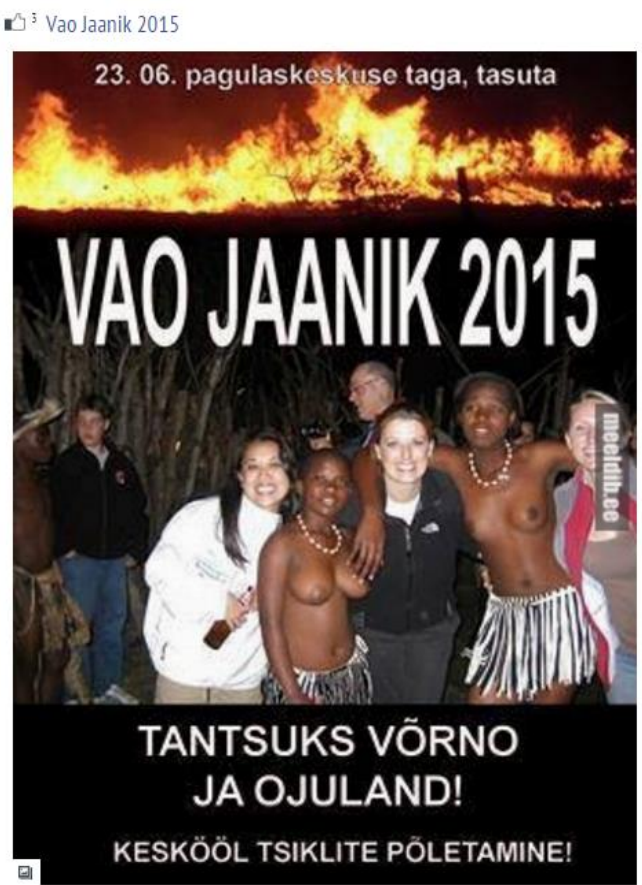

Figure 17. St. John's eve in Vao. (Hannes) Võrno and (Kristiina) Ojuland (anti-refugee politicians) will play music for dancing. At midnight motorcycles will be burned ${ }^{17}$

(meeldib.ee)

Although the number of refugees has been very small in Estonia and the actual contacts with them have been minimal, these clashes between us and the Others create humorous juxtapositions and allow to speculate on how the up to now alien cultures could influence the Estonian culture in the future. In the process of debating the refugee crisis, images of refugees are paired with local iconic cultural phenomena, creating connections between semantically diverse fields and producing absurdity as a result. National grand narratives offer a congenial text resource for such remixes (on the intertextual uses of the Estonian national epic Kalevipoeg, see Kõresaar 2006: 105; Voolaid \& Laineste 2013: 30). The remixes in turn show the nation's collective behaviour in a distorting mirror. The emblematic work of Oskar Luts' Kevade ("Spring", 1912) and Eno Raud's Naksitrallid ("Three jolly fellows", 1975) are good examples of this (Figure 18-19): 


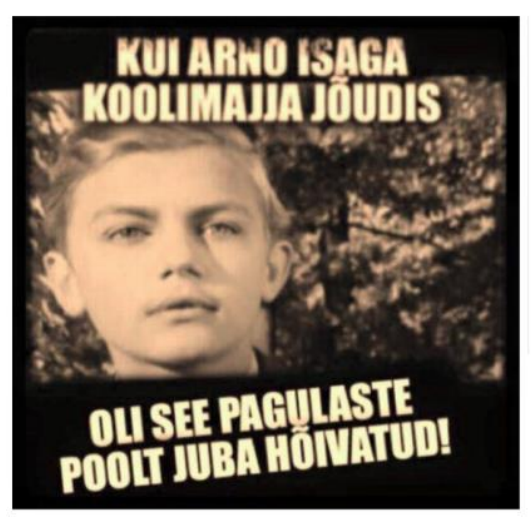
PrinceOfEstonia $\odot$ PrinceOfEstonia · Sep 15 \#pagulased

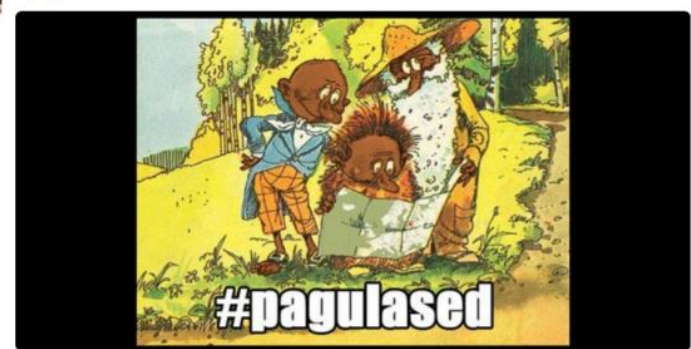

Figure 18. When Arno and his father reached the schoolhouse, refugees had already taken over the place (18/1). Naksitrallid are characters from a well-known children's book of the same name. Their faces are darkened in the remix (18/2) (meeldib.ee; twitter.com)

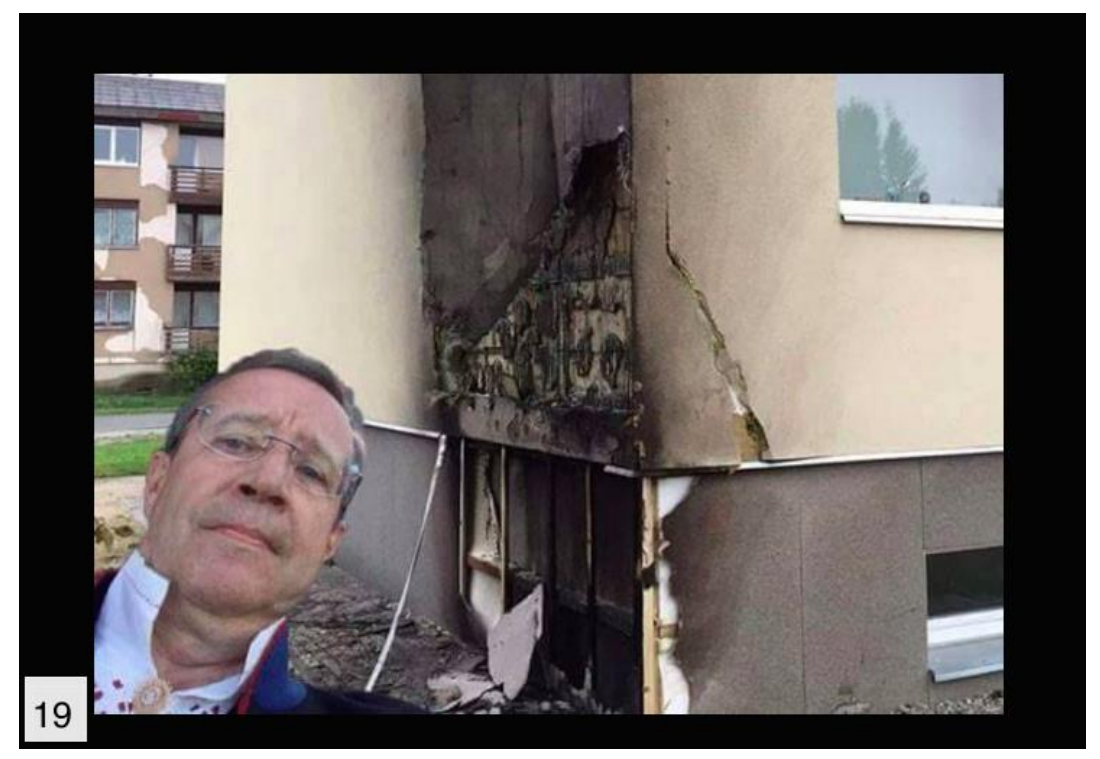

Figure 19. Memetic selfie of the President of Estonia Toomas Hendrik Ilves, photoshopped to the image of the burned Vao refugee center (Sept. 2, 2015) (Facebook)

\section{Conclusion}

In an era when everyone possessing enough knowledge and digital equipment can post a potential meme, the hybridity and transculturality of texts becomes their desired feature. Successful cultural units are then mediated globally to a very wide range of audiences who consume them in different ways (Warnick 2007). This web-based folk culture fosters active participation via low-cost social network environments and entertainment sites such as YouTube or the Estonian meeldib.ee. Internet users are not passive observers but engage in creating, editing and sharing content, and this tendency is further supported by easy access to technological devices in our pockets and desks connected to the web (see Howard 2012: 4445 on the development of the rhetoric of vernacular authority in early 1970s). Online social spaces provide a platform where the global and transcultural corpora of texts are discussed, shared, and modified to fit the target cultures. The more open to modifications and alterations and borrowings a text is, the more it is used, repeated, remixed, shared. 
Internet memes have become an important part of community and social life within the contemporary online world, carrying out numerous social roles. They "tell the news" (Börzsei 2013), being sometimes the first and primary texts that people turn to when something significant is happening (e.g. as a response to the refugee crisis). Internet memes also provide opportunities to be creative and playful in a social way (Danet et al. 1997) and this adds social capital to the ones involved (Nissenbaum \& Shifman 2015). As Knobel \& Lankshear (2005) have stressed, the ludic and timely quality of a meme ensures its contagiousness, fecundity, and longevity. Thus, memes have to be "playfully serious" in order to become popular. In Estonia, memes (in this article, the 2015 refugee crisis commentary was taken as a case in point) go through remixing to enhance the socially critical point they want to deliver. It is the mundane, universal topics such as weekly routine or gender relations that do not change much in the course of dissemination, thus acting as virals: they get across easily in the form they already have.

However, we are witnessing a growing intensity of remixing and thus also a heightened possibility of memes turned into virals. This is also underlined by Börzshei (2013), who points out that meme users nowadays are active and knowledgeable in everyday issues. Internet memes have become a part of their everyday vocabulary: they use memes actively to comment on the problems and scandals they find relevant. Meme creators use reference frames from popular culture to come up with multi-layered hybrid blends accessible to large audiences. Not everything in a meme can be understood by all potential repicipents: its complex multi-layered structure consists of references that are accessible to most, side by side with those that are unfamiliar and remain "closed" (Coulson 2015). On the other hand, many layers will remain accessible and this is usually enough for a meme to become popular.

The processes of localisation and globalisation in enacted when mainly English (in the case of this study, also Russian) language cultural texts enter into local cultures (Shabtai \& Shifman 2014). The term glocalisation used in this context (Robertson 1995) challenges the idea that cultural homogenization and heterogenization are clear-cut categories and offer an alternative by showing how local culture mixes various influences into a coherent and meaningful whole (Shifman et al. 2014). Global models are reworked by groups through the process of resemiotisation and entextualisation into multifaceted, hybrid ones. In the case of Estonian memes, the textual part is often based on wordplay and is as such largely untranslatable. The visual part, on the other hand, may refer to locally known symbols and cultural narratives.

YouTube, Facebook and other online environments combine the serious with the humorous, addressing issues ranging from acute political conflicts (the Tahrir square or Euromaidan ones, to name just a few of recent cases) to mundane details from the daily life (images of children, pets, weekly routine, etc.). The commentary on topical political issues is communicated through various moulds or meme templates in video and picture format. In the course of active meme circulation and in testing out different images, wordplays, jokes and their combinations, one symbol may start to represent the entire complex problem, like in the above analysis the alien customs in the consumption of food and drink (where Muslims' refusal of alcohol and pork was taken to underline the otherness of the refugees in Estonia and elsewhere). Intertextuality adds to the dissemination of memes: the more possible interpretations or ways of modifying the meme, the more "offsprings" is sparks. As Baym (1993: 172) insightfully stated, the most popular online texts are the ones that "lend themselves to multiple interpretations, they are about emotionality, and their quality is inconsistent. It is their over-coded nature which makes comparing perspectives both possible and fun".

The refugee discussion in Estonia reached much further than just dedicated Facebook pages (meeldib.ee, "Estonians against refugee quotas", etc.), Twitter hashtags (\#pagulased), 
or Youtube videos on the internet: the humorous approach to the delicate issue fulfilled a supportive function in the actual political discussion. Through humour, the discussion undermined and attacked the official statements and got people involved in saying out what they thought. Thus, internet memes provide a way to talk about various different topics, whether concerning pop culture, the common everyday topics or the current political events (Häkkinen \& Leppänen 2014). They provide an entry point, sometimes even the first exposure to topical "hot" and debated issues, mixing critical commentary with absurd metacomments. Memes can be political - they do more than just criticise. They involve people. At the same time, virals targeting simple mundane problems such as work week routine of internet behaviour may be distributed in higher numbers, but the level of engagement (as indicated by the number of likes, comments, and further remixes or derivates) remains low. Intertextuality together with the resemiotisation of cultural items is and has always been an integral part of the cultural processes, the examples of jokes affirming the claim.

Technologically mediated vernacular expression provides an excellent entry point for the study of cross-cultural, intertextually rich communication. Unforeseen possibilities to document, trace, and analyse cultural units that travel and change as they move from one cultural frame to another are developing under the auspices of digital humanities. Talking about the hybridisation of vernacular expression, Blank (2012: 6) stresses that like all folklore, computer-mediated folklore is comprised of patterns. When contextualised into the wider cultural settings, these patterns inform us of developments and trends in one culture as well as of influences from outside that shape and enrich it.

\section{Notes}

${ }^{1}$ The article was supported by institutional research grant IUT22-5 from the Estonian Ministry of Education and Research and by the European Union through the European Regional Development Fund (Centre of Excellence in Estonian Studies).

${ }^{2}$ E.g. KGB Museum in Tallinn (KGBcafe.ee), a comedy series about life in Soviet Estonia (http://etv.err.ee/l/meelelahutus/ensv), etc.

${ }^{3}$ Archival reference: 1964, Rapla, RKM II 422, 510. In the archival material, the same joke frequently occurs with other characters like Lenin, Brezhnev, or Chrushchev; e.g. How tall is Chrushchev? - I don't know in centimetres, but for us he's up to the throat (= we are fed up).

${ }^{4}$ Archival reference: 1985 Vändra, RKM I 21, 335 (35).

5 Sometimes, in order to retain the original succinctness of the joke, the Russian language punchline is retained. One favourite topic, deciphering party names, used this technique: e.g. reinterpreting the meaning of CСCP (abbreviation of Союз Советских Социалистических Республик "USSR" the former Union of Soviet Socialists Republic), in which case also Russian original jokes circulated in Estonia (еg Смерть Сталина Спасет Россию, Smert' Stalina spasaet Rossiju meaning "the death of Stalin will save Russia"; see Voolaid 2010a: 68-70).

${ }^{6}$ Note that the first joke in Figure 3. was also known with another target, the elephant. This indicates that the target culture may mix the original scripts quite freely, although not all versions become widely spread and popular.

${ }^{7}$ E.g. www.meeldib.postimees.ee, www.igav.ee, both also available through Facebook.

${ }^{8}$ Such as www.knowyourmeme.com and www.9gag.com.

${ }^{9}$ The Center of Excellency for Estonian Studies at the Estonian Literary Museum (20152023) has a specialised work group that focuses on contemporary (media) culture, including internet folklore. 
${ }^{10}$ See www.planet.ee; www.perekool.ee.

${ }^{11}$ Most of the examples come from the Estonian entertainment site meeldib.ee.

12 ggag is one of the better known entertainment sites where users can upvote, downvote, and comment on the humorous items posted on the social media platform.

${ }^{13}$ See https://www.youtube.com/watch?v=iUPNymvAgoA.

${ }^{14}$ Similarly, Varis \& Blommaert (2015) discuss the famous propaganda poster "Keep calm and carry on".

15 The Soviet Russian anti-alcohol propaganda poster featuring an illustration of a man refusing a drink by making a dismissive gesture towards a hand offering a shot glass was created as part of an anti-alcohol campaign that was launched following the death of Soviet Union dictator Joseph Stalin in the 1953.

${ }^{16}$ Personal communication with Reet Hiiemäe (2016), who observed and recorded this hybrid ritual custom in 2012.

${ }^{17}$ A reference to a protest motorcycle ride to Vao as a demonstration against the refugees in July 2015.

\section{References}

Adams, B. (2005). Tiny Revolutions in Russia: Twentieth-Century Soviet and Russian History in Anecdotes. New York/London: Routledge Curzon.

Astapova, A. (2015). 'Why all dictators have moustaches: Political jokes in contemporary Belarus'. HUMOR: International Journal of Humor Research, 28 (1), pp. 71-91.

Bauman, R. \& Briggs, C. L. (1990). 'Poetics and performance as critical perspectives on language and social life'. Annual Review of Anthropology, 19, pp. 59-88.

Baym, N. K. (1993). 'Interpreting soap operas and creating community: Inside a computermediated fan culture'. Journal of Folklore Research 30 (2/3), pp. 143-176.

Baym, N. K. (1995). 'The performance of humour in computer-mediated communication'. Journal of Computer-Mediated Communication 1(2). [Online] http://onlinelibrary.wiley.com/doi/10.1111/j.1083-6101.1995.tb00327.x/full. [Accessed 15 February 2016.]

Berger, A. A. (1995). Blind Men and Elephants: Perspectives on Humour. New Brunswick: Transaction.

Blank, T. (2012). 'Introduction', in Blank, T. (ed.), Folk Culture in the Digital Age. The Emergent Dynamics of Human Interaction, Logan, Utah: Utah State University Press, pp. 1-24.

Blank, T. (2013). Folk Humour, Celebrity Culture, and Mass-Mediated Disasters in the Digital Age. Madison: University of Wisconsin Press.

Börzsei, L. (2013). 'Makes a meme instead: A concise history of internet memes'. New Media Magazine: Digital Visual Culture 7, pp 152-193. [Online] http://www.newmediastudies.nl/publications/ebook_no7.pdf. [Accessed 15 February 2016.]

Buchel, B. (2012). Internet Memes as Means of Communication, University of Brno MA thesis; [Online] http://is.muni.cz/th/384995/fss_m/Buchel_thesis.pdf. [Accessed 15 February 2016.]

Coulson, S. (2015). 'No one will ever wonder why, they said: Conceptual blending and humorous memes cross the road, they said'. Paper presented at the International Society of Humour Studies Conference. Oakland, CA, USA, 29 June - 3 July. 
Danet, B., Wachenhauser, T., Bechar-Israeli, H., Cividalli, A. \& Rosenbaum-Tamari, Y. (1995). 'Curtain time 20:00 GMT: Experiments in virtual theatre on Internet Relay Chat'. Journal of Computer Mediated Communication 1 (2). [Online] http://onlinelibrary.wiley.com/doi/10.1111/j.1083-6101.1997.tb00195.x/full. [Accessed 15 February 2016.]

Danet, B., Ruedenberg-Wright, L. \& Rosenbaum-Tamari, Y. (1997). “"HMMM...WHERE'S THAT SMOKE COMING FROM?" Writing, play and performance on Internet Relay Chat'. Journal of Computer-Mediated Communication 2 (4). [Online] http://onlinelibrary.wiley.com/doi/10.1111/j.1083-6101.1997.tb00195.x/full. [Accessed 15 February 2016.]

Davies, C. (1990). Ethnic Humour Around the World: A Comparative Analysis. Bloomington: Indiana University Press.

Davies, C. (2011). Jokes and Targets. Bloomington: Indiana University Press.

Dawkins, R. (1976). The Selfish Gene. London: Oxford University Press.

Draitser, E. (1998). Taking Penguins to the Movies. Detroit: Wayne State University Press.

Dundes, A. \& Abrahams, R.D. (1969). 'On elephantasy and elephanticide'. Psychoanalytic Review 56, pp. 225-241.

Gorny, E. (2005). A Creative History of the Russian Internet. Goldsmiths College, University of London $\quad \mathrm{PhD}$ [Online] http://elmcip.net/sites/default/files/files/attachments/criticalwriting/gorny.pdf. [Accessed 25 February 2016.]

Graham, S. (2009). Resonant Dissonance. The Russian Joke in Cultural Context. Evanston, IL: Northwestern University Press.

Graham, S. \& Mesropova, O. (2009). Reinventing Humour and Satire in Post-Soviet Russia. Columbus, OH: Slavica.

Helmy, M. M. \& Frerichs, S. (2013). 'Stripping the boss: The powerful role of humour in the Egyptian Revolution 2011'. Integrative Psychological \& Behavioural Science, 47(4), pp. $50-81$.

Howard, R. (2012). 'How counter-culture helped put the 'vernacular' in Vernacular Webs"', in Blank, T. (ed.), Folk Culture in the Digital Age. The Emergent Dynamics of Human Interaction. Logan, Utah: Utah State University Press, pp. 25-45.

Hutcheon, L. (2000). A Theory of Parody: The Teachings of Twentieth-Century Art Forms. Urbana: University of Illinois.

Häkkinen, A. \& Leppänen, S. (2014). 'YouTube meme warriors: Mashup videos as political critique', Varieng $15 . \quad$ [Online] http://www.helsinki.fi/varieng/series/volumes/15/hakkinen_leppanen/

Knobel, M. \& Lankshear, C. (2005). 'Memes and affinities: Cultural replication and literacy education'. Paper presented to the annual NRC, Miami, November 30. [Online] http://everydayliteracies.net/files/memes2.pdf. [Accessed 15 February 2016.]

Knobel, M., \& Lankshear, C. (2007). New Literacies: Everyday Practices and Classroom Learning. Buckingham: Open University Press

Knobel, M. and Lankshear, C. (2008). 'Remix: The art and craft of endless hybridisation'. Journal of Adolescent \& Adult Literacy, 52 (1), pp. 22-33.

Kõresaar, E. 2006. 'Kollektives Gedächtnis und nationale Textgemeinschaft im postsowjetischen Estland: Ein Beispiel über die intertextuelle Verwendung des Nationalepos "Kalevipoeg" in den estnischen Lebensgeschichten', in Bartens, H.H., Röhrborn, K., Sagaster, K. \& Winkler, E. (eds.), Ural-Altaische Jahrbücher. Internationale Zeitschrift für uralische und altaische Forschung. Neue Folge. Wiesbaden: Harrassowitz, pp. 101-124. 
Krikmann, A. (2004). Netinalju Stalinist / Интернет-анекдоты о Сталине / Internet Humour about Stalin. Tartu: Estonian Literary Museum, The Centre of Cultural History and Folkloristics in Estonia. [Online] http://www.folklore.ee/ kriku/HUUMOR/STALIN_FIN.pdf. [Accessed 25 February 2016.]

Krikmann, A. (2009). 'Jokes in Soviet Estonia'. Folklore 43: 43-66. [Online] https://www.folklore.ee/folklore/vol43/krikmann.pdf. [Accessed 8 September 2016.]

Kuipers, G. (2002). 'Media culture and internet disaster jokes: Bin Laden and the attack on the World Trade Center'. European Journal of Cultural Studies 5 (4), pp. 450-470.

Laineste, L. (2009). Political jokes in Post-socialist Estonia (2000-2007), in Krikmann, A. \& Laineste, L. (eds.), Permitted Laughter: Socialist, Post-Socialist and Never-Socialist Humour. Tartu: EKM Teaduskirjastus, pp. 41-72.

Laineste, L. (2012). 'They didn't batter us enough: Soviet nostalgia in post-socialist humour'. Paper presented at the conference Humour in conventional and unconventional politics, November 5-9, Galati, Romania.

Laineste, L. (2015). “„...VÕI NAGU SELLES ANEKDOODIS”: Anekdoot veebisuhtluses' ('Or like in this joke: The joke in online communication'). Keel ja Kirjandus, pp. 652-666. [Online] http://kjk.eki.ee/ee/issues/2015/8-9/688. [Accessed 24 February 2016.]

Laineste, L. (forthcoming). Emotions in Estonian online discussions about refugees, in Chovanec, J. \& Molek-Kozakowska, K. (eds.), Representing the Other in European Media Discourses. Amsterdam: John Benjamins.

Leppänen, S., Kytölä, S., Jousmäki, H., Peuronen, S. \& Westinen, E. (2014). Entextualisation and resemiotisation as resources for (dis)identification in social media, in Seargeant, P. \& Tagg, C. (eds.), The Language of Social Media: Identity and Community on the Internet. Basingstoke: Palgrave Macmillan, pp. 112-136. [Online] https://www.tilburguniversity.edu/upload/a3d5524e-4413-4772-9f96-

9fe0ee714c6f_TPCS_57_Leppanen-etal.pdf. [Accessed 20 September 2016.]

Lin, C., Huang, Y. \& Hsu, J.Y. (2014). 'Crowdsourced explanations for humorous internet memes based on linguistic theories'. Proceedings of the Second AAAI Conference on Human Computation and Crowdsourcing (HCOMP 2014). [Online] http://www.aaai.org/ocs/index.php/HCOMP/HCOMP14/paper/viewFile/8980/8964. [Accessed 15 February 2016.]

Milner, R. M. (2013). 'Pop polyvocality: Internet memes, public participation, and the occupy wall street movement'. International Journal of Communication 7, pp. 23572390.

Miltner, K. M. (2014). “"There's no place for lulz on LOLCats": The role of genre, gender and group identity in the interpretation and enjoyment of an internet meme'. First Monday, 19 (8).

MINAS-5 report $2011=$ Miinimumnõuded varjupaigataotlejate sisserände haldamisele, vastuvõtule ja kaitsele Eestis ('Minimal requirements of maintainting, accepting and defending immigration of refugees in Estonia') (2011). Rahvusvahelise kaitse saanud isikute integratsioon Eesti ühiskonda: Olemasoleva süsteemi kaardistus ja ettepanekud ('Integrating persons who have granted international protection to Estonian society: Mapping the present system and new suggestions'). [Online] http://www.pagulasabi.ee/sites/default/files/public/rahvusvahelise-kaitse-saanud-isikuteintegratsioon-eesti-uhiskonda.pdf. [Accessed 25 February 2016.]

Nissenbaum, A, \& Shifman, L. (2015). 'Internet memes as contested cultural capital: The case of 4chan /b/ board'. New Media \& Society. [Online] http://dx.doi.org/10.1177/1461444815609313. [Accessed 22 December 2016.] 
Oring, E. (2003). Engaging Humour. Urbana: Illinois University Press.

Robertson, R. (1995). 'Glocalisation: Time-space and homogeneity-heterogeneity', in Featherstone, M., Lash, S. \& Robertson, R. (eds.), Global Modernities. London: Sage, pp. 25-44.

Ross, A. (1998). The Language of Humour. London: Routledge.

Shabtai-Boxman, L. \& Shifman, L. (2014). 'Evasive targets: Deciphering polysemy in mediated humour'. Journal of Communication 64 (5), pp. 977-998.

Shifman, L. (2006). 'Humour in the age of digital reproduction: Continuity and change in internet-based comic texts'. International Journal of Communication 1, pp. 187-209, [Online] http://ijoc.org/index.php/ijoc/article/viewFile/11/34. [Accessed 24 February 2016.]

Shifman, L. (2014). Memes in Digital Culture. Cambridge: MIT Press.

Shifman, L., Levy, H. \& Thelwall, M. (2014). 'Internet jokes: The secret agents of globalisation?' Journal of Computer-Mediated Communication 19, pp. 727-743.

Sparke, M. (2013). 'From global dispossession to local repossession: Towards a worldly cultural geography of Occupy Activism', in Johnson, N. C., Schein, R. H. \& Winders, J. (eds.), The Wiley-Blackwell Companion to Cultural Geography, First Edition. Malden, MA: Wiley-Blackwell, pp. 387-408.

Varis, P. \& Blommaert, J. (2015). 'Conviviality and collectives on social media: Virality, memes, and new social structures'. Multilingual Margins 2 (1), p. 31-45.

Vickery, J. (2014). 'The curious case of confession bear: The reappropriation of online macro-image memes'. Information, Communication \& Society 17 (3), pp. 301-325. [Online] http://dx.doi.org/10.1080/1369118X.2013.87105. [Accessed 15 February 2016.]

Voolaid, P. (2010a). 'Humorous interpretations of abbreviations as a socio-cultural phenomenon'. Folklore. Electronic Journal of Folklore 46, pp. 61-82. [Online] http://folklore.ee/folklore/vol46/voolaid.pdf. [Accessed 15 February 2016.]

Voolaid, P. (2010b). 'Animal lore in Estonian riddle periphery', in Stasulane, A. (ed.), Kulturas studijas: Zinatnisko rakstu krajums ('Scientific Papers: Animals in Literature and Culture'). Daugavpils: Daugavpils University Academic Press "Saule", pp. 34-46.

Voolaid, P. (2011). 'Recent developments in pupils' riddle usage in Estonia', in Csúcs, S., Falk, N., Tóth, V. \& Zaicz, G. (eds.), Congress XI Internationalis Fenno-Ugristarum: Dissertationes Sectionum et Symposiorum ad Ethnologiam, Folkloristicam et Mythologiam. Piliscsaba: Reguly Társaság, pp. 207-213.

Voolaid, P. \& Laineste, L. (2013). 'We believe! Online representations of the Olympic Winner as a Mythic Hero'. Folklore. Electronic Journal of Folklore 54. [Online] http://folklore.ee/folklore/vol54/voolaid_laineste.pdf. [Accessed 15 February 2016.]

Warnick, B. (2007). Rhetoric Online: Persuasion and Politics on the World Wide Web. New York: Peter Lang.

Wienkler-Piepho, S. (1998). 'Böse Zungen im Gelächter der Geschlechter'. Kuckuck. Notizen zu Alltagskultur und Volkskunde 1, pp. 28-33. 